\title{
The study of the incidence of pregnant women with sickle cell disease
}

\author{
Jyoti Lagoo, Arpita Lagoo*
}

Department of Obstetrics and Gynecology, Lt. BRKMGMC, Jagdalpur, Chhattisgarh, India

Received: 09 July 2019

Accepted: 09 September 2019

\section{*Correspondence:}

Dr. Arpita Lagoo,

E-mail: drarpitalagoo2019@gmail.com

Copyright: ( $)$ the author(s), publisher and licensee Medip Academy. This is an open-access article distributed under the terms of the Creative Commons Attribution Non-Commercial License, which permits unrestricted non-commercial use, distribution, and reproduction in any medium, provided the original work is properly cited.

\section{ABSTRACT}

Background: The sickle cell disease is major public health problem which causes high morbidity and mortality in India. It is observed that SCD is scourge in Chhattisgarh since long past. Sickle cell disease is a term for a group of genetically inherited disorders characterized by production of abnormal hemoglobin. "Hemoglobin-S" results from a point mutation in the beta globin gene. The main objective is to study the incidence of pregnant women with sickle cell disease.

Methods: It is a hospital based prospective study. It was conducted at Obstetrics and Gynecology department of LTBRKM Govt. Medical College, Jagdalpur, Chhattisgarh. The study was carried out from August 2014 to October 2015. The study included screening of all patients attending antenatal clinic and in labour ward during emergency. 75 cases were found to be sickling positive. Permission from Institutional Ethics Committee was obtained.

Results: The incidence of SCD in India is $44 \%$, in Chhattisgarh is 17\%.At our institute in pregnant women is $1.75 \%$. The incidence of $\mathrm{HbAs}$ group was $70.66 \%$ and $\mathrm{HbSS}$ was $26.66 \%$. In $\mathrm{Hb}$ AS group maximum $47 \%$ patients were in age group of 26-30 years. and also in same age group the incidence of HbSS group was 60\%. In age group of 31-35 years. $22 \%$ of patients were of $\mathrm{HbAS}$ group, but only $10 \%$ of patients were of $\mathrm{HbSS}$ group. HbAS group and $\mathrm{HbSS}$ group the percentage of primi gravida were $49 \%$ and $60 \%$ respectively. It is noted that in HbAS group only $3 \%$ of patients had parity $>4$, but in HbSS group it was $10 \%$.

Conclusions: In conclusion, it has been shown that the clinical statuses of the most sickle cell diseases patience were not seriously affected by pregnancy if they are given appropriate prenatal care. All pregnant women should be screened for sickle sell hemoglobinopathy in endemic region, like in our state Chhattisgarh.

Keywords: Incidence, Pregnant women, Sickle cell disease

\section{INTRODUCTION}

The sickle cell disease is major public health problem which causes high morbidity and mortality in India. It is observed that SCD is scourge in Chhattisgarh since long past.

Sickle cell disease is a term for a group of genetically inherited disorders characterized by production of abnormal hemoglobin. "Hemoglobin-S" results from a point mutation in the beta globin gene. This mutation substitutes thymine for adenine in the second nucleotide of the sixth codon of the beta globin gene results in substitution of, glutamic acid and formation of $\mathrm{Hb}$ "S".

The sickle cell gene is known to be wide - spread, reaching its highest incidence in equatorial Africa, but occurring also in parts of Sicily and southern Italy, Northern Greece, Southern Turkey, the Middle East, Saudi Arabia, especially the Eastern province and much of central India. 
The most common Sickle cell disorder is the heterozygous form of hemoglobin ( $\mathrm{Hb} \mathrm{AS}$ ) or Sickle cell trait. $\mathrm{Hb} \mathrm{AS}$ is a minor disorder occurring in 1 in 12 adult African Americans. ${ }^{1}$

The most common major sickle hemoglobinopathy is the homozygous form of hemoglobin $\mathrm{S}$ (HbSS) that occurs in approximately 1 in 625 African Americans at birth. HbSC has a frequency in the African American population comparable to HbSS (1:833). Hemoglobin S, when combined with $\beta$ thalassemia is known as $\mathrm{HbS}$ Beta. Thal and also may result in a clinically significant hemoglobinopathy with a prevalence of approximately 1 in 1667 African Americans. ${ }^{2}$

Almost same prevalence rates in Panika Agharia, Gond and Halba (Bastar) population of the region. ${ }^{3}$

Pregnant women with sickle cell anemia usually have some degree of cardiac dysfunction from ventricular hypertrophy. There is increased preload and decreased after load with a normal ejection fraction and a high cardiac output. Chronic hypertension worsens this. ${ }^{4}$

\section{METHODS}

It is a hospital based prospective study. It was conducted at Obstetrics and Gynecology department of LTBRKM Govt. Medical College, Jagdalpur, Chhattisgarh. The study was carried out from August 2014 to October 2015. The study included screening of all patients attending antenatal clinic and in labour ward during emergency. 75 cases were found to be sickling positive. All cases followed till delivery and peupecium.

Detailed history of patient was taken on admission who are known for sickling positive and also those patients who are admitted in labour ward during emergency and those sickling status were not known, including the age, history of amenorrhea, parity, socioeconomic status, time of onset of labour pains if present previous pregnancy outcome, previous menstrual cycles/O any painful crisis episodes, sickling status of previous child/O MTP if done after prenatal diagnosis. Then $\mathrm{H} / \mathrm{O}$ prior genitourinary infection, upper respiratory tract infection was asked. General examination of patient was done to note temperature, maternal pulse, pallor, edema, signs of dehydration, icterus, blood pressure, respiratory rate, cardiovascular and respiratory system was examined. Then per abdomen examination was done to note liver, spleen, the height of uterus, lie, and presentation, presenting parts, position, uterine contraction and foetal heart sounds. Per vaginal examination was done if patient was admitted with complaint of labour pain. Laboratory studies was done included complete blood count, reticulocyte count, sickling test and $\mathrm{Hb}$ electrophoresis (those sickling status were not known) urinalysis to detect asymptomatic bacteria
In terms of patient care: We focused our attention on: Antenatal Care, Intranatal care. After delivery mothers were noted for: Pallor, temperature, foul smelling lochia, wound infection. Permission from Institutional Ethics Committee was obtained. From each and every patient included in the study, initially informed individual consent was taken.

\section{Inclusion criteria}

- Study included screening of all patients attending antenatal clinic and in labour ward during emergency

- Patients willing to participate in the study.

\section{Exclusion criteria}

- Patients with any other serious ailments

- Patients not willing to participate in the study.

\section{Statistical analysis}

The obtained data will be compiled, analyzed and interpreted. The data analysis will involve an understanding the incidence of sickle cell disease. Data will be analyzed through SPSS.

\section{RESULTS}

Table 1 shows the incidence of sickle cell hemoglobinopathy. The incidence of Sickle cell disease in India is $44 \%$, in Chhattisgarh is $17 \%$, and at JLN Hospital is $1.75 \%$. The incidence of sickle cell disease is more in Chhattisgarh than our institute (JLN Hospital).

Table 1: Incidence of sickle cell hemoglobinopathy.

\begin{tabular}{|ll|}
\hline Place & Incidence (IN \%) \\
\hline India & $44 \%$ \\
\hline Chhattisgarh & $17 \%$ \\
\hline At JLN Hospital & $1.75 \%$ \\
\hline
\end{tabular}

Table 2: HB electrophoresis pattern.

\begin{tabular}{|lll|}
\hline Hb pattern & No. of cases & Percentage \\
\hline Sickle cell trait(HbAs) & 53 & $70.66 \%$ \\
\hline $\begin{array}{l}\text { Sickle cell } \\
\text { anemia(HbSS) }\end{array}$ & 20 & $26.66 \%$ \\
\hline Sickle $\beta$-thalassemia & 2 & $2.6 \%$ \\
\hline
\end{tabular}

Table 2 shows HB Electrophoresis pattern. In present study the number of cases of sickle cell trait (HbAs) were 53 cases i.e.70.66\%, sickle cell anemia (HbSS) was 20 cases i.e. $26.66 \%$. Sickle $\beta$ thalassemia 2 cases i.e. $2.6 \%$.

In our study more number of cases is of sickle cell trait with $70.66 \%$ and less number of cases is seen in sickle $\beta$ thalassemia that is only 2 cases with $2.6 \%$. 
Table 3 shows age distribution. In HbAS group 16 patients $(30 \%)$ are seen in the age group 20-25 years. 25 cases $(47 \%)$ are seen in the age group 26-30 years and 12 cases ( $22 \%$ ) are seen in the age group 31-35 years.

In HbSS group 6 cases (30\%) are seen in the age group 2025 years. 12 cases $(60 \%)$ are seen in the age group 26-30 years and 2 cases $(10 \%)$ are seen in the age group 31-35 years.

Table 3: Age distribution.

\begin{tabular}{|lllllll|}
\hline Age & \multicolumn{2}{l}{ HbAS } & \multicolumn{2}{l}{ HbSS } & \multicolumn{2}{l|}{ HbS $\beta-$} \\
group & \multicolumn{2}{l}{ group } & \multicolumn{2}{l|}{ group } & \multicolumn{2}{l|}{ Thal Group } \\
in year & No & $\%$ & No & $\%$ & No & \% \\
\hline $20-25$ & 16 & $30 \%$ & 6 & $30 \%$ & - & - \\
\hline $26-30$ & 25 & $47 \%$ & 12 & $60 \%$ & 1 & $50 \%$ \\
\hline $31-35$ & 12 & $22 \%$ & 2 & $10 \%$ & 1 & $50 \%$ \\
\hline
\end{tabular}

Table 4: Gravida distribution.

\begin{tabular}{|c|c|c|c|c|c|c|}
\hline \multirow[t]{2}{*}{ Gravida } & \multicolumn{2}{|c|}{$\begin{array}{l}\text { HbAS } \\
\text { group }\end{array}$} & \multicolumn{2}{|c|}{$\begin{array}{l}\text { HbSS } \\
\text { group }\end{array}$} & \multicolumn{2}{|c|}{$\begin{array}{l}\text { Hbs } \beta \text { - } \\
\text { thal group }\end{array}$} \\
\hline & No & $\%$ & No & $\%$ & No & $\%$ \\
\hline Primi & 26 & $49 \%$ & 12 & $60 \%$ & - & - \\
\hline Gravida2 & 16 & $30 \%$ & 5 & $25 \%$ & 1 & $50 \%$ \\
\hline Gravida3 & 9 & $16 \%$ & 1 & $5 \%$ & 1 & $50 \%$ \\
\hline Gravida $>4$ & $2 \mathrm{G}$ & $3 \%$ & 2 & $10 \%$ & - & - \\
\hline
\end{tabular}

In $\mathrm{HbS} \beta$ Thal group no cases are seen in the age group 20-25 years. Only one case was seen in the age group 2630 years and also in the $31-40$ years age group one case was seen.

$\mathrm{Hb}$ AS group maximum $47 \%$ patients were in age group of 26-30 years. and also, in same age group the incidence of $\mathrm{HbSS}$ group was $60 \%$. In age group of 31-35years $22 \%$ of patients were of $\mathrm{HbAS}$ group, but only $10 \%$ of patients were of HbSS group.

Table 4 shows gravida distribution. In HbAS group and $\mathrm{HbSS}$ group the percentage of primi gravida were $49 \%$ and $60 \%$, Gravida 2 was $30 \%$ and $25 \%$, Gravida 3 was $16 \%$ and $5 \%$ respectively. It is noted that in $\mathrm{HbAS}$ group only $3 \%$ of patients had parity $>4$, but in $\mathrm{HbSS}$ group it was $10 \%$. This difference may be due to history of unsuccessful pregnancy outcome in HbSS group.

Table 5: Booked and unbooked.

\begin{tabular}{|lll|}
\hline Cases & No. & $\%$ \\
\hline Booked & 32 & $42 \%$ \\
\hline Unbooked & 43 & $57 \%$ \\
\hline
\end{tabular}

Table 5 shows booked and unbooked cases. From above table it is evident that 43 cases i.e. $57 \%$ of cases of SCD were directly admitted in emergency labour ward and were unbooked and 32 cases i.e. $42 \%$ were booked. Unbooked cases were more than the booked cases.
Table 6 shows pregnancy complications. From the above table it is observed that the most common complication during pregnancy in SCD was PIH, it was $22 \%$ in $\mathrm{HbAS}$ group, $5 \%$ in $\mathrm{HbSS}$ group. $10 \%$ of $\mathrm{HbSS}$ group and $9 \%$ of HbAS group developed UTI. URTI found in $10 \%$ of HbSS group and $3.7 \%$ of $\mathrm{HbAS}$ group. IUGR found only in $\mathrm{HbAS}$ group it was $5.6 \% .10 \%$ abortion rate was found in $\mathrm{HbSS}$ group and $3.7 \%$ in $\mathrm{HbAS}$ group.

Table 6: Pregnancy complications.

\begin{tabular}{|c|c|c|c|c|c|c|}
\hline \multirow{2}{*}{$\begin{array}{l}\text { Complications } \\
\text { in pregnancy }\end{array}$} & \multicolumn{2}{|c|}{$\begin{array}{l}\text { HbAS } \\
\text { group }\end{array}$} & \multicolumn{2}{|c|}{$\begin{array}{l}\text { HbSS } \\
\text { group }\end{array}$} & \multicolumn{2}{|c|}{$\begin{array}{l}\text { HbS } \beta \text {-thal } \\
\text { group }\end{array}$} \\
\hline & No & $\%$ & No & $\%$ & No & $\%$ \\
\hline PIH & 12 & 22 & 1 & 5 & - & - \\
\hline UTI & 5 & 9 & 2 & 10 & - & - \\
\hline URTI & 2 & 3.7 & 2 & 10 & - & - \\
\hline IUGR & 3 & 5.6 & - & - & - & - \\
\hline Abortion & 2 & 3.7 & 2 & 10 & - & - \\
\hline $\begin{array}{l}\text { Preterm delivery } \\
\text { (<37weeks) }\end{array}$ & 7 & 13.2 & 3 & 15 & - & - \\
\hline
\end{tabular}

Preterm delivery occurred in only 7 cases i.e. $15 \%$ of $\mathrm{HbSS}$ group and 15 cases i.e.13.2\% of HbAS group.

- PIH - Pregnancy induced hypertension

- UTI - Urinary tract infection

- URTI - Upper respiratory tract infection

- IUGR - Intrauterine growth retardation.

\section{DISCUSSION}

Veille et al reported during pregnancy the basal hemodynamic state characterized by high cardiac output and increases blood volume is augmented. ${ }^{5}$ Cunningham FG et al reported most women tolerate pregnancy without problems, complications such as severe preeclampsia or serious infection may result in ventricular failure. ${ }^{6}$

Eisenstein et al reported women with HbSS have an increased incidence of spontaneous abortion (variously reported as 19-28\%), still births (reports vary between 8 and $12 \%$ ), preterm delivery and neonatal deaths (rates ranging from 3 to $20 \%$ having been reported). The overall rate of fetal loss of somewhere between 34 and $49 \%{ }^{7}$ Harris et al reported that alteration in the space of red blood cells containing sickle hemoglobin was the result of polymerization of hemoglobin molecule. ${ }^{8}$

Hahn and Gillespie delineated the conditions affecting sickling in vitro like $\mathrm{PH}$, temperature, oxygen tension etc. They observed that exclusion of oxygen was a prerequisite to sickling and the phenomenon could be reversed on re-exposure to the gas. ${ }^{9}$

Therapy for sickle cell patients is directed toward prevention and treatment of sickle cell crisis and the effects of chronic anemia. Several therapeutic agents can treat the effect of the under laying genetic defect of SCD 
at the molecular level, such as cytotoxic agents that increase the percentage of hemoglobin $\mathrm{F}$ or hemoglobin A. In 1982, 5-azacytidine was the first cytotoxic agent used to stimulate the $1-\mathrm{Hb}$ gene activation. ${ }^{10}$

\section{CONCLUSION}

The incidence of Sickle cell hemoglobinopathy in this study was $1.75 \%$ out of which 70.66 patients were sickle cell trait (HbAS), 26.66\% were sickle cell anemia (HbSS) and $2.6 \%$ patients were sickle cell Beta thalassemia. $60 \%$ patients of HbSS group were in age group of 26-30 years. and $47 \%$ of HbAS group were also in same age group.

In conclusion, it has been shown that the clinical statuses of the most sickle cell diseases patience were not seriously affected by pregnancy if they are given appropriate prenatal care. Studies have shown that there is a significant improvement in morbidity and mortality of mother and neonate in SCD. All pregnant women should be screened for sickle cell hemoglobinopathy in endemic region, like in our state Chhattisgarh.

Sickle cell diseases are hereditary diseases so genetic counseling should be discussed and prenatal diagnosis can be offered to couples if appropriate. Good antenatal care, prompt diagnosis and aggressive treatment of complications intrapartum and postpartum care will further improve fetomaternal outcome.

Funding: No funding sources Conflict of interest: None declared

Ethical approval: The study was approved by the Institutional Ethics Committee

\section{REFERENCES}

1. Stein Berg C, Jones JA, Detter JC. A Screening protocol for a prenatal population at risk for inherited hemoglobin disorders: result of its application to a group of Southeast Asians and blacks. Am J Obset Gynecol. 1984;150(4):333-41.

2. ACOG Technical bulletin. Hemoglobinopathies in pregnancy. Am College Obstet Gynecol. 1996;53(2):184-94.

3. Negi RS. The Incidence of sickle -cell Trait in Two Bastar Tribes. JSTOR.1962;62:84-6.

4. Gandhi SK, powers JC, nomeir AM. The pathogenesis of acute pulmonary edema associated with hypertension. N Engl J Med. 2001;344:17-22.

5. Veille J, Hanson R. Left ventricular systolic and diastolic function is pregnant patients with sickle cell disease. Am J Obstet Gynecol. 1994;170(1):107-10.

6. Cunningham FG, Pritchard JA, Hankins GDV. Idiopathic cardiomyopathy or compounding cardio vascular events. Obstet Gynecol. 1986;67(2):157-68.

7. Eisenstein MI, Posner AC, Friedman S. Sickle cell anemia in pregnancy. A review of the literature with additional case histories. Am J Obstet Gynecol. 1956;72(3):622-34.

8. Harris JW. Aggravation of clinical manifestations of folic acid deficiency by small daily doses of vitamin B12. Arch Int Med. 1956;21(3):461-7.

9. Huck EV. Sickle cell anemia. Arch Intern Med. 1927;39(2):233-54.

10. Ley TJ, Demimonde J, Anagnou N. 5-Azacytidine selectively increases $\mathrm{T}$-globin synthesis in a patient with Thalassemia. N Engl J Med. 1982;307(24):1469-75.

Cite this article as: Lagoo J, Lagoo A. The study of the incidence of pregnant women with sickle cell disease. Int J Reprod Contracept Obstet Gynecol 2019;8:3950-3. 